\title{
An easy and reliable method for establishment and maintenance of tissue cultures of Nicotiana tabacum cv. TAPM 26
}

\author{
Nurliyana binti Moh Hussein $^{1,2}$ ID , Fahrul Huyop ${ }^{1}$ ID, Yilmaz Kaya $^{1,3^{*} \text { ID }}$ \\ ${ }^{1}$ Department of Biosciences, Faculty of Science, Universiti Teknologi Malaysia, \\ Johor/Malaysia \\ ${ }^{2}$ Faculty of Engineering Technology, Universiti Malaysia Pahang, Pahang/Malaysia \\ ${ }^{3}$ Department of Agricultural Biotechnology, Faculty of Agriculture, Ondokuz Mayis \\ University, Samsun/Turkey
}

\begin{abstract}
In vitro regeneration of Nicotiana tabacum was efficiently achieved using growth regulators combination supplemented into semi-solid MS medium using leaves from 1-month-old plant as explants. The growth regulators used were NAA for auxin $\left(0.0,1.0,2.0\right.$, and $\left.3.0 \mathrm{mgL}^{-1}\right)$ and BAP $\left(0.0,0.5,1.0,2.5\right.$, and $\left.5.0 \mathrm{mgL}^{-1}\right)$. The effects of growth regulator combination were assessed based on a number of callus formation, shoots formation and fresh callus weight. The maximum number of callus formation was $100 \%$ at five hormone combination, observed at the fourth week after culture. Maximum number of shoots produced per explant was 21.4 shoots at $1.0 \mathrm{mgL}^{-1} \mathrm{BAP}+3.0 \mathrm{mgL}^{-1} \mathrm{NAA}$, after 6 weeks of culture. The maximum callus fresh weights were obtained at $0.5 \mathrm{mgL}^{-1} \mathrm{BAP}+1.0 \mathrm{mgL}^{-1} \mathrm{NAA}$ after 6 weeks $(9.92 \mathrm{~g})$. The best combination for shoots regeneration of Nicotiana tabacum was 1.0 $\mathrm{mgL}^{-1} \mathrm{BAP}+3.0 \mathrm{mgL}^{-1} \mathrm{NAA}$. And the best combination for heaviest callus production was $0.5 \mathrm{mgL}^{-1} \mathrm{BAP}+1.0 \mathrm{mgL}^{-1} \mathrm{NAA}$.
\end{abstract}

Article History

Received 06.07.2020

Accepted 16.08.2020

Keywords

Nicotiana tabacum TAPM 26,

Callus,

Tissue culture,

Maintenance tissue culture,

Callus formation

Abbreviations BAP, 6-benzyl-aminopurine; IAA, indole-3-acetic acid; MS, Murashige and Skoog medium (1962); NAA, napthaleneacetic acid

\section{Introduction}

Plant tissue culture covers the development of selected plant tissue and grown aseptically for indefinite duration on a nutrient medium under controlled conditions (Mohammed, 2020). Tissue culture usually applied as a medium for micropropagation, creation of virus-free plants (Arvas et al., 2018), genetics transformation (Kutty et al., 2011; Kaya et al., 2013) and it is also demonstrated more effective in the creation of secondary metabolites,

${ }^{1}$ Correspondence: yilmaz.kaya@omu.edu.tr 
for examples, phenolics (Ozyigit, 2008), Juglone (Kocacaliskan et al., 2018) and Anthocyanins (Marchev et al., 2020) etc. The most regular technique in tissue culture is micropropagation which defined as a technique to procreate genetically clonal plantlets by using tissue culture methods and it supports in creating pathogen-free stock plants (Arvas et al., 2018) or genetically superior clones that cannot be propagated by seeds or plant that with low propagation efficiency in conventional vegetative propagation (Kutty et al., 2010). Moreover, plant cell exhibits its totipotency that every single cell can regenerate into a whole new plant.

Shoot regeneration for tobacco from an explant has achieved attention in the past and has promising application in the area of plant biotechnology (Deo et al., 2010). In addition, Kaya (2010) showed that adventitious regeneration of tobacco plant has a higher regeneration potential via embryogenesis when explants derived from cotyledons were used. Thus, the aim of the research is to establish an easy and reliable technique for maintenance of tissue cultures of Nicotiana tabacum cv. TAPM 26.

\section{Materials and Methods}

\subsection{Culture Conditions}

The seed of Nicotiana tabacum cv. TAPM 26 was provided by National Tobacco Board Kota Bharu Kelantan. The study was achieved in the Department of Biosciences, Faculty of Science, Universiti Teknologi Malaysia. In vitro plant regeneration was pursued at $25 \pm 2^{\circ} \mathrm{C}$ in either dark or light with a $16 \mathrm{~h}$ photoperiod and $6 \mathrm{~h}$ dark distributed by cool white fluorescent tubes. The tissue culture medium was heated to melting solutes and then distributed in tissue culture tubes for seed germination of tobacco plant and tubes for regeneration.

\subsection{Basic Media Preparation}

Basic media was prepared based on Murashige and Skoog (1962) containing mineral salts, micronutrients and vitamins, supplied with $20 \mathrm{gL}^{-1}$ sucrose, $0.1 \mathrm{gL}^{-1}$ myo-inositol and $3.2 \mathrm{gL}^{-1}$ phytagel. The $\mathrm{pH}$ of the plant culture media was adjusted to 5.7 with either $1 \mathrm{~N} \mathrm{NaOH}$ (sodium hydroxide) before sterilization. The tissue culture media were sterilized at $121^{\circ} \mathrm{C}$ 
for $21 \mathrm{~min}$ in an autoclave. After autoclaving, the medium was left to cool down to 40 to $45^{\circ} \mathrm{C}$ before combination of growth hormone (BAP and NAA) were added.

\subsection{Preparation of Explants Material}

Approximately 30 seeds of Nicotiana tabacum was placed in a test tube supplied with 2 $\mathrm{mL}$ of sterilizing solution (70 \% ethyl alcohol). It was mixed gently for $20 \mathrm{~min}$. Then the sterilising solution removed and washed all the seeds with double sterile water for 3 times. The seeds were put onto a sterile petri dish for drying and then the seeds were transferred to germination medium. Only 5 seeds were put onto each petri dishes. After a few days the germinated seeds will be ready to be used as a young plantlet that will be the source of explants for plant tissue culture work. The leaves of plantlet were sterile as they grow in the tissue culture systems under controlled parameters. In 4 weeks, the old plantlets were used as sources of explant. Callus induction and shoots regeneration from callus was obtained by using MS medium modified with auxin and cytokinin. The callus was induced from leaf explant on media contained MS (Murashige and Skoog, 1962) salts, vitamins, 30

$\mathrm{gL}^{-1}$ sucrose, $8 \mathrm{gL}^{-1}$ agar powder, 6-benzylaminopurine $(0.0,0.5,1.0,2.5$ or 5.0) and 1naphthalene acetic acid $\left(0.0,1.0,2.0\right.$ or $\left.3.0 \mathrm{mgL}^{-1}\right)$.

The $\mathrm{pH}$ was adjusted during each experiment to $5.7 \pm 1$ with $1 \mathrm{~N} \mathrm{NaOH}$ or $1 \mathrm{~N} \mathrm{HCl}$ using an electronic $\mathrm{pH}$ indicator. All the operations and inoculations were carried out under aseptic conditions in laminar airflow cabinet.

\subsection{Data Analysis}

All the assays were carried out in triplicates and the data were subjected to statistical analysis of one-way ANOVA using SPSS 15.0 for Windows. A value of $\mathrm{P}<0.05$ was considered to be significant.

\section{Results and Discussion}

The explants produced callus on the one month after cultivation on all combination of NAA and BAP at room temperature and $16 \mathrm{~h}$ light under plant growth chamber. The results achieved in the aspects of callus weight and percentage of callus from hypocotyl explants. 
The first step in the start of plant tissue culture represents the disinfection of the explant or seed. The efficiency of the surficial sterilization technique has an important effect on the development and growth of the plant for tissue culture. Standard surficial sterilization technique for starting a tissue culture of members of the tobacco plants comprise the application of alcohol, sodium hypochlorite (Steyn et al., 1996; Ganapathi et al., 2004).

\subsection{Effect of BAP/NAA on Callus Fresh Weight}

In Figure 1, the maximum average weights of callus form were detected at $0.5 \mathrm{mgL}^{-1} \mathrm{BAP}$ $+1.0 \mathrm{mgL}^{-1} \mathrm{NAA}$ The maximum mean weight produces was $9.92 \mathrm{~g}$ while the minimum mean weight was $0.127 \mathrm{~g}$ observed at the presence of zero growth regulator. The product of experiments was analyzed using one-way ANOVA and the results were significant for a value $\mathrm{P}<0.05$. From the previous researches, the maximum mean weight produced was $1.81 \mathrm{~g}$ at 0.2 $\mathrm{mgL}^{-1} \mathrm{BAP}$ and $3.0 \mathrm{mgL}^{-1} \mathrm{NAA}$ (Ali et al., 2007). This showed that lower concentration of BAP and NAA created heavier and bulkier callus but too low or too high concentration may retard the growth of the callus. Figure 2 showed the best callus formed in terms of fresh callus weight as described in Figure 1.

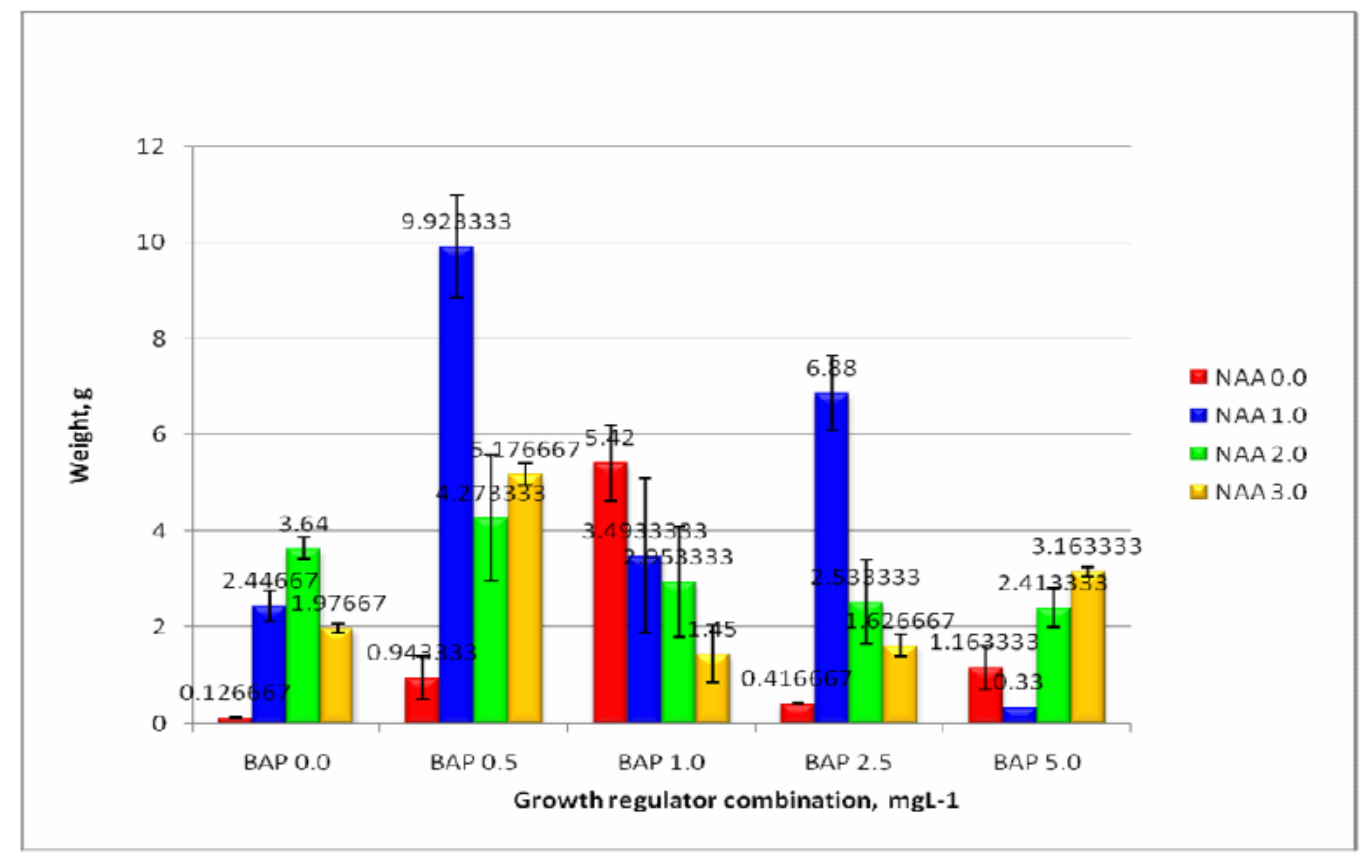

Figure 1. The average weight of callus on different combination of growth regulator 


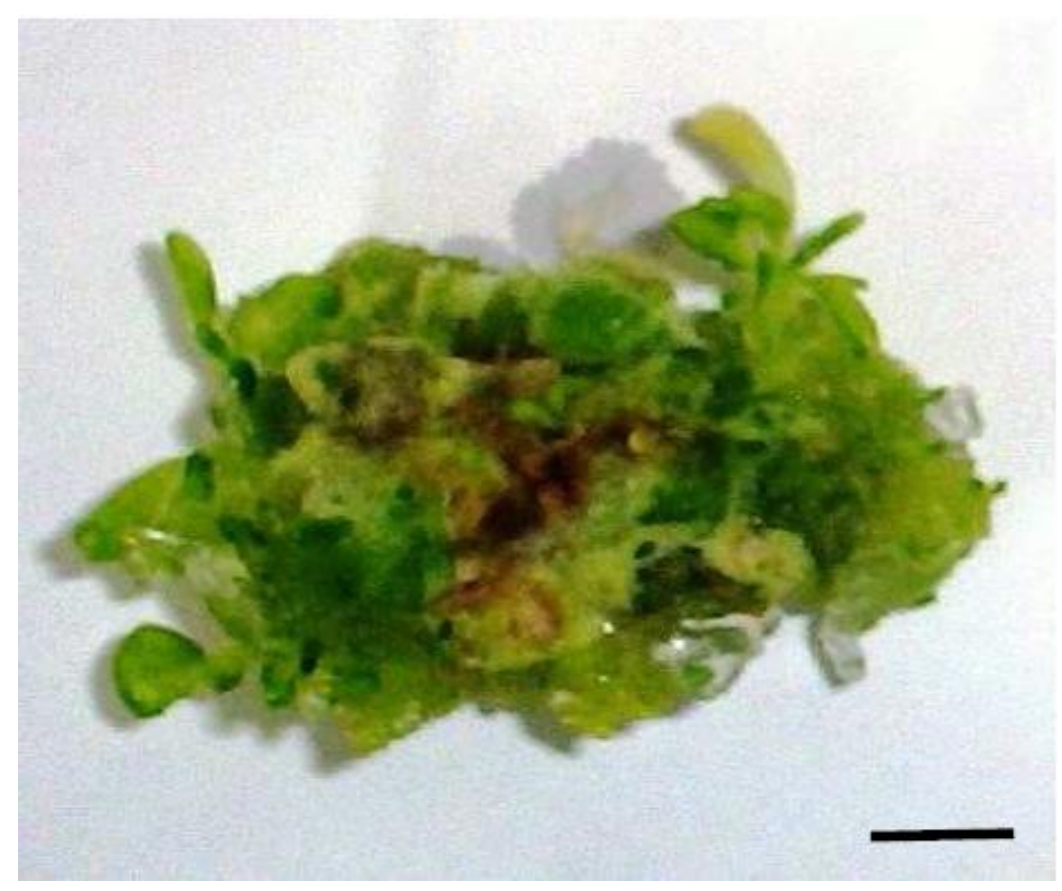

Figure 2. Fresh callus at $\mathrm{MS}+0.5 \mathrm{mgL}^{-1} \mathrm{BAP}+1.0 \mathrm{mgL}^{-1} \mathrm{NAA}$. (Scale bar $\left.=1.0 \mathrm{~cm}\right)$

\subsection{Effect of BAP/NAA on Callus Formation}

At $3.0 \mathrm{mgL}^{-1} \mathrm{NAA}$ concentration; the callus formation was lower than others (Table 1). The same result was observed for the maximum concentration BAP which only formed $20 \%$ of callus compared to other BAP and NAA combinations. This showed that explants need both growth regulators combination to form callus.

Table 1. Percentage of callus formed for each growth regulator combinations

\begin{tabular}{|c|c|c|c|c|c|c|}
\hline \multirow{2}{*}{\multicolumn{2}{|c|}{$\begin{array}{c}\text { Hormone } \\
\text { combination } \mathrm{mgL}^{-1}\end{array}$}} & \multicolumn{5}{|c|}{ BAP } \\
\hline & & $0.0 \%$ & 0.5 & 1.0 & 2.5 & 5.0 \\
\hline \multirow{4}{*}{$\begin{array}{l}\mathrm{N} \\
\mathrm{A} \\
\mathrm{A}\end{array}$} & 0.0 & $\begin{array}{c}33.3 \% \\
\text { callus } \\
\text { formation }\end{array}$ & $\begin{array}{c}86.7 \% \\
\text { callus } \\
\text { formation }\end{array}$ & $\begin{array}{c}80.0 \% \\
\text { callus } \\
\text { formation }\end{array}$ & $\begin{array}{c}60.0 \% \\
\text { callus } \\
\text { formation }\end{array}$ & $\begin{array}{c}20.0 \% \\
\text { callus } \\
\text { formation }\end{array}$ \\
\hline & 1.0 & $\begin{array}{c}53.3 \% \\
\text { callus } \\
\text { formation }\end{array}$ & $\begin{array}{c}86.7 \% \\
\text { callus } \\
\text { formation }\end{array}$ & $\begin{array}{c}86.7 \% \\
\text { callus } \\
\text { formation }\end{array}$ & $\begin{array}{c}93.3 \% \\
\text { callus } \\
\text { formation }\end{array}$ & $\begin{array}{c}33.3 \% \\
\text { callus } \\
\text { formation }\end{array}$ \\
\hline & 2.0 & $\begin{array}{c}53.3 \% \\
\text { callus } \\
\text { formation }\end{array}$ & $\begin{array}{c}100 \% \\
\text { callus } \\
\text { formation }\end{array}$ & $\begin{array}{c}100 \% \\
\text { callus } \\
\text { formation }\end{array}$ & $\begin{array}{c}100 \% \\
\text { callus } \\
\text { formation }\end{array}$ & $\begin{array}{c}73.3 \% \\
\text { callus } \\
\text { formation }\end{array}$ \\
\hline & 3.0 & $\begin{array}{c}13.3 \% \\
\text { callus } \\
\text { formation }\end{array}$ & $\begin{array}{c}100 \% \\
\text { callus } \\
\text { formation }\end{array}$ & $\begin{array}{c}100 \% \\
\text { callus } \\
\text { formation }\end{array}$ & $\begin{array}{c}73.3 \% \\
\text { callus } \\
\text { formation }\end{array}$ & $\begin{array}{c}66.7 \% \\
\text { callus } \\
\text { formation }\end{array}$ \\
\hline
\end{tabular}

In Figure 3, the maximum number of callus induction percentage was $100 \%$ at MS 
media containing $0.5 \mathrm{mgL}^{-1} \mathrm{BAP}+2.0 \mathrm{mgL}^{-1} \mathrm{NAA}, 1.0 \mathrm{mgL}^{-1} \mathrm{BAP}+2.0 \mathrm{mgL}^{-1}, 2.5 \mathrm{mgL}^{-1}$ $\mathrm{BAP}+2.0 \mathrm{mgL}^{1} \mathrm{NAA}, 0.5 \mathrm{mgL}^{-1} \mathrm{BAP}+3.0 \mathrm{mgL}^{-1} \mathrm{NAA}$ and $1.0 \mathrm{mgL}^{-1} \mathrm{BAP}+3.0 \mathrm{mgL}^{-1}$ $\mathrm{mgL}^{-1} \mathrm{NAA}$. Maximum concentration of hormone combination gives a medium percentage of calli formation, about $66.7 \%$. This indicated that too low or too high concentration of growth regulator may inhibit the formation of calluses.

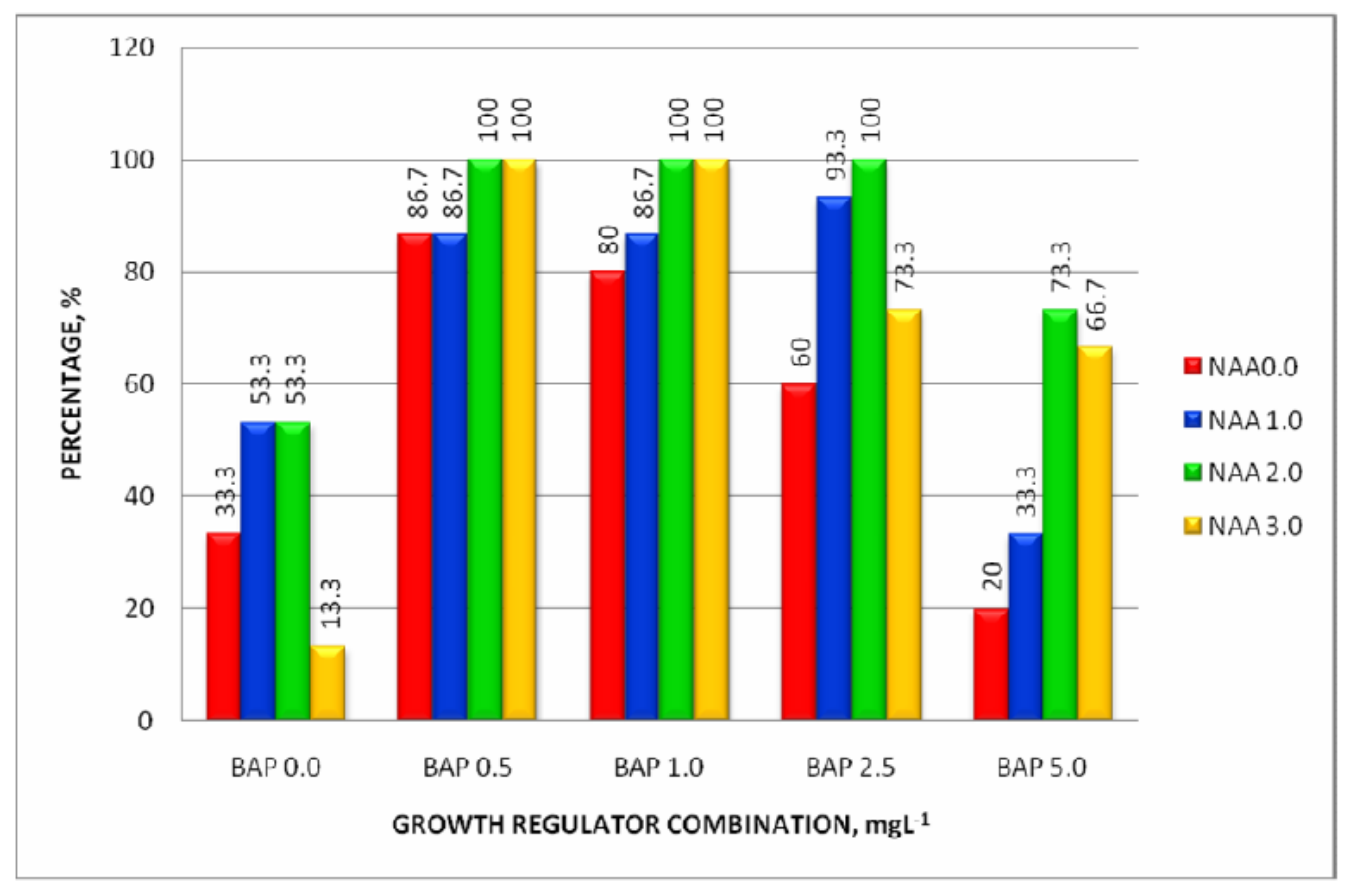

Figure 3. The percentage of callus formed in different growth regulators combination

\subsection{Effect of BAP/NAA on Shoots Induction}

In Figure 4, it demonstrationed that shoots need $2.0 \mathrm{mgL}^{-1}$ and $3.0 \mathrm{mgL}^{-1} \mathrm{NAA}$ concentrations. The highest average number of shoots was $21.4 \pm 2.13$ per explant. At 0.0 $\mathrm{mgL}^{-1}$ and $1.0 \mathrm{mgL}^{-1}$ of NAA concentration, there was no shoot formed. At all BAP concentrations, there were shoots formed and it varied upon the combination. The highest average number of shoots per explant was obtained from the combination of $1.0 \mathrm{mgL}^{-1} \mathrm{BAP}+$ $3.0 \mathrm{mgL}^{-1} \mathrm{NAA}$. The results were analysed using one-way ANOVA and the results were significant for a value $\mathrm{P}<0.05$. The lowest number of shoots for per explants was observed on MS medium supplemented with $2.0 \mathrm{mgL}^{-1} \mathrm{NA}$ (1.067 shoots per explants). Roots initiation was not detected on all explants after 6 weeks culture. This showed that the NAA concentration should be higher to achieve rooting or it takes longer time to regenerate. Figure 
5 shows the shoot callus for the best combination growth regulator used as described in Figure 4.

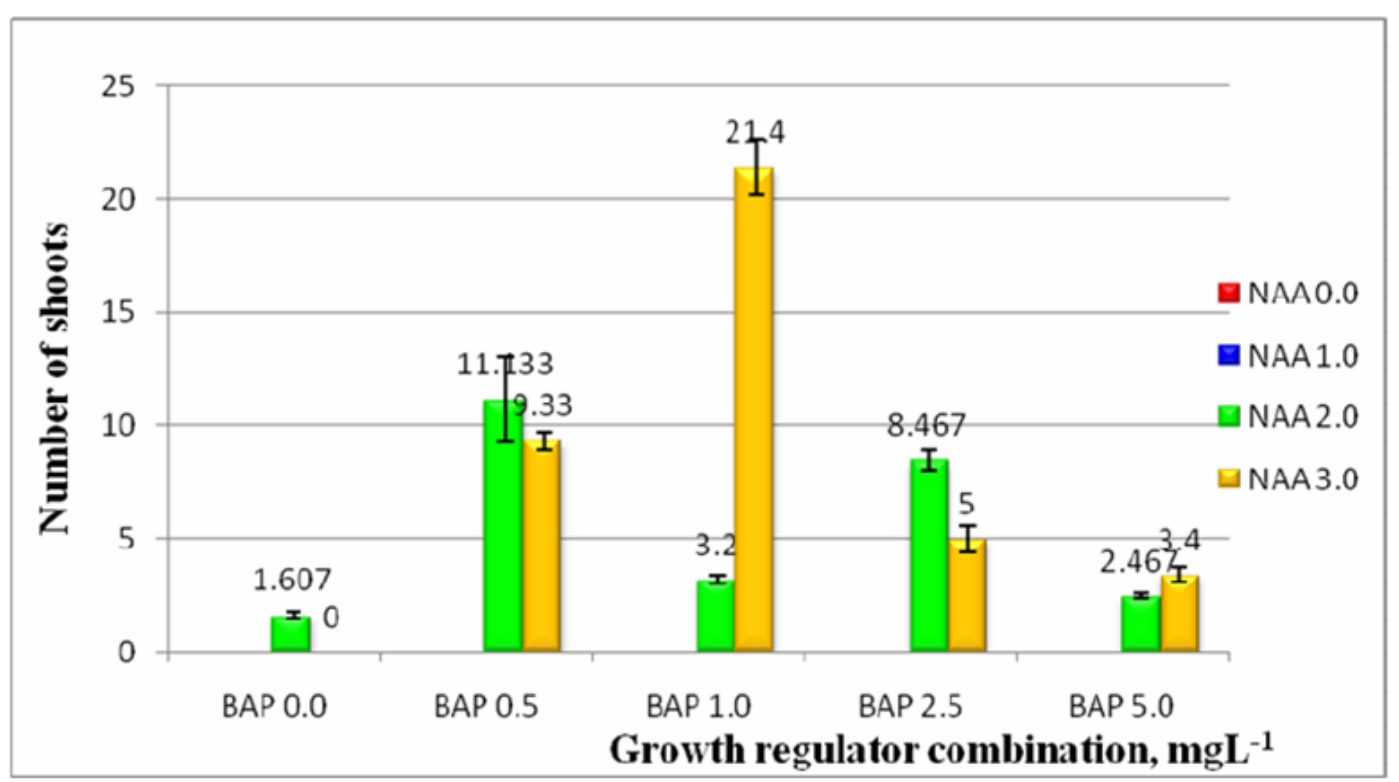

Figure 4. The average number of shoots formed

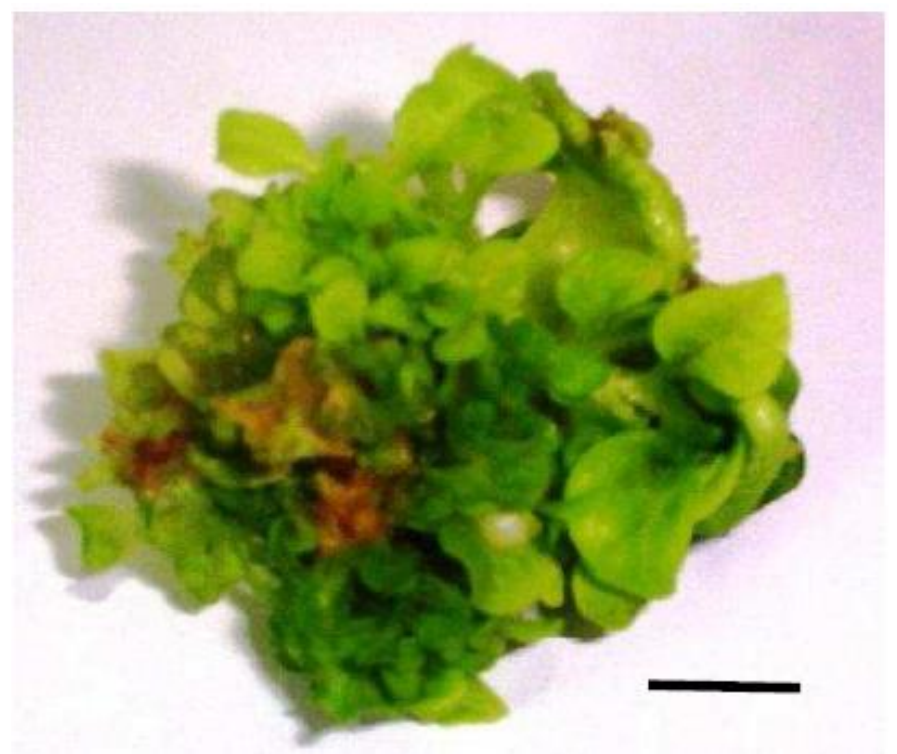

Figure 5. Shoots regenerated at 1.0mgL-1 BAP+3.0mgL-1 NAA. $($ Scale bar $=0.5 \mathrm{~cm})$

From Table 2, it was indicated that different sizes of callus formed at different combination of growth regulator. From the observation, the combination of $0.5 \mathrm{mgL}^{-1} \mathrm{BAP}$ and $2.0 \mathrm{mgL}^{-1}$ NAA showed the best biggest callus size formed. 
Table 2. Different sizes of callus formed regenerates based on varies growth regulator concentration after treatment for 6 weeks

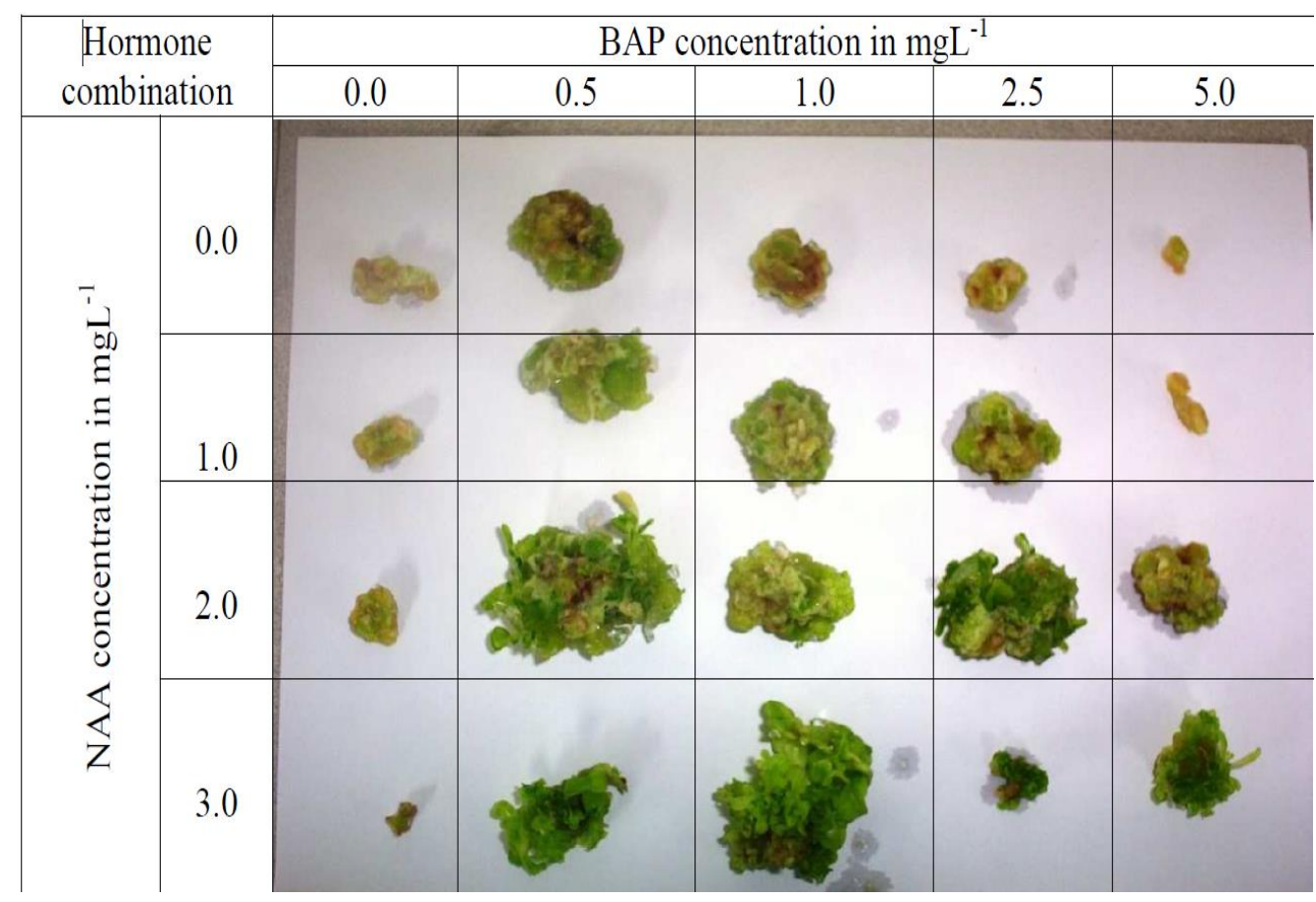

The tobacco plant is created of several repetitive modules in its vegetative part, successively generated by meristems. Tissue culture methods via calli have become an essential tool for plant biotechnology such as Gossypium hirsutum L. (Ozyigit et al., 2007), Impatiens balsamina (Taha et al., 2009), Lycopersicon esculentum Mill. (Jawad et al., 2020), Oryza sativa (Kaya and Karakutuk, 2018) Tagetes minuta (Latifian et al., 2018), Citrullus lanatus cv. Round Dragon (Ganasan and Huyop, 2010) and many others. The explant type and hormones are also significant influences for in vitro plant regeneration (Kumar and Reddy, 2010). Explant was a critical parameter when optimizing tissue culture methods (Kumar et al., 2011). Therefore, choice of appropriate explants is an important factor of tissue culture of Nicotiana tabacum (Kaya, 2010). Growing the explant of Nicotiana tabacum under different concentrations of plant growth hormones such as BAP, NAA as very essential (Table 1). The combination of plant growth hormone was crucial in determining the tissue culture performance resulting in plant regenaration seen in shoot cultures. The present study (Figures 3 and 4) established the good combination of hormone in the media preparation where the shoot formation from regeneration of callus were established.

In conclusion, the results obtained showing the success of tissue culture of Nicotiana tobacum with the best hormone combination would be $\mathrm{MS}+1.0 \mathrm{mgL}^{-1} \mathrm{BAP}+3.0 \mathrm{mgL}^{-1}$ 
NAA for production of maximum number of callus and also the highest shoots formation.

The callus started to form at fourth weeks after cultivation and the shoots started to initiate two weeks later. Suitable growth regulator combination promote the optimum growth explants and also induced the callus and shoots formation. It also helps to shorten the time taken to initiate callus and shoots. The present method demonstrated that Nicotiana tabacum TAPM 26 was successfully propagated by organogenesis and can be applied for further research such as transgenic Nicotiana tabacum TAPM 26.

\section{References}

Ali, G., Hadi, F., Ali, Z., Tariq, M., Khan, M.A.(2007). Callus induction and in vitro complete plant regeneration of different cultivars of tobacco (Nicotiana tabacum L.) on media of different hormonal concentration, Journal of Biotechnology, 6 (4): 561-566.

Arvas, Y.E., Aksoy, H.M., Kaya, Y., 2018. Patates bitkisinde biyoteknolojik çalışmalar, International Journal of Life Sciences and Biotechnology, 1(1): 37-47.

Deo, P.C., Tyagi, A.P., Taylor, M., Harding, R., Becker, D. 2010. Factors affecting somatic embryogenesis and transformation in modern plant breeding, The South Pacific Journal of Natural and Applied Sciences, 28: 27-40.

Ganasan, K., Huyop, F. 2010. In vitro regeneration of Citrullus lanatus cv. Round Dragon, Journal of Biological Sciences, 10(2): 131-137.

Ganapathi, T.R., Suprasanna, P., Rao, P.S., Bapat, V.A. 2004. Tobacco (Nicotiana tabacum L.) - A model system for tissue culture interventions and genetic engineering. Indian Journal of Biotechnology, 3: 171-184.

Jawad, Z.A., Turker, M., Ozdemir, F.A. 2020. Effect of different plant growth regulator on in vitro propagation of endangered plant; yellow tomato (Lycopersicon esculentum Mill.), International Journal of Agriculture Forestry and Life Sciences, 4(1): 92-98.

Kaya, Y. 2010. In vitro Plant Regeneration of Tobacco. PhD Thesis. Universiti Teknologi, Malaysia..

Kaya, Y., Yilmaz, S., Marakli, S., Gozukirmizi, N., Huyop, F. 2013. Transformation of Nicotiana tabacum with dehE gene, Journal of Food Agriculture and Environment, 11(34): 777-780.

Kaya, Y., Karakütük, S. 2018. Farklı büyüme düzenleyicilerin Türk kır çeltiği rejenerasyonuna etkisi, Anadolu Tarım Bilimleri Dergisi, 33(3): 226-231.

Kocacaliskan, I., Akgul, T., Erisen, S. 2019. Effect of juglone on seed germination and seedling growth of four common vegetables, International Journal of Life Sciences and Biotechnology, 2(1): 43-49.

Kutty P.C., Parveez, G.K.A., Huyop, F. 2010. An easy method for Agrobacterium tumefaciens-mediated gene transfer to Nicotiana tabacum cv. TAPM26, Journal of Biological Sciences, 10(6): 480-489.

Kutty, P.C., Parveez, G.K.A., Huyop F. 2011. Agrobacterium tumefaciens-infection strategies for greater transgenic recovery in Nicotiana tabacum cv. TAPM26, International Journal of Agricultural Research, 6(2): 119-113.

Kumar, N., Reddy, M.P. 2010. Plant regeneration through the direct induction of shoot buds from petiole explants of Jatropha curcas: a biofuel plant, Annals of Applied Biology, 156: 367-375. 
Latifian, E., Arvas, Y.E., Kaya, Y. 2018. Tagetes minuta bitkisinin mikro üretimi üzerine farklı BAP ve IAA konsantrasyonlarının etkileri, International Journal of Life Sciences and Biotechnology, 1(2): 96-104.

Marchev, A.S., Georgiev, M.I. 2020. Plant in vitro systems as a sustainable source of active ingredients for cosmeceutical application. Molecules, 25(9): 2006.

Mohammed, S. 2020. Effects and quantity ranges of some auxins on embryogenic callus induction from upland rice cultivars: An overview, International Journal of Life Sciences and Biotechnology, 3(2): 197-204

Ozyigit, I.I., Kahraman, M.V., Ercan, O. 2007. Relation between explant age, total phenols and regeneration response in tissue cultured cotton (Gossypium hirsutum L.), African Journal of Biotechnology, 6(1): 3-8.

Ozyigit, I.I. 2008. Phenolic changes during in vitro organogenesis of cotton (Gossypium hirsutum L.) shoot tips, African Journal of Biotechnology, 7(8): 1145-1150.

Steyn Anita, E. , Brink, J.A., Coetzer, L.A. 1997. A comparison of culture methods for tobacco (Nicotiana tabacum) anthers, South African Journal of Plant and Soil, 14: 27-30.

Taha, A.M., Wagiran, A., Ghazali, H., Huyop, F., Parveez, G.K.A. 2009. In vitro regeneration of garden balsam, Impatiens balsamina using cotyledons derived from seedlings, Biotechnology, 8(1): 44-52. 